\title{
IT-Based Monitoring and Evaluation System for Vocational Students in Industrial Work Practice
}

\author{
Widiyanti ${ }^{1}$, Djoko Kustono ${ }^{1}$, Eddy Sutadji ${ }^{1}$, Ahmad Dardiri ${ }^{1}$ and Andika Bagus N.R.P ${ }^{2}$ \\ ${ }^{I}$ Department of Mechanical Engineering, State University of Malang, Malang, Indonesia \\ ${ }^{2}$ Department of Civil Engineering Education, State University of Malang, Malang, Indonesia \\ widiyanti.ft@um.ac.id, kustono1609@gmail.com,ahmad.dardiri.ft@um.ac.id,andika.bagus.ft@um.ac.id,
}

\begin{abstract}
Keywords: Monitoring and Evaluation System, IT, Work Practice.
Abstract: $\quad$ This research aimed to develop the IT-based monitoring and evaluation system application (Si-Monev) for industrial work practice participants that fall into the criteria of validity, practicality, and effectiveness to assess the students' expertness competency and to validate the usage in the program. This research used the Waterfall Model for software development based on the requirements needed. The software's assessment process used the Developmental Model of Plomp, The General Model of Education Problem Solving. SiMonev validation showed that it had fulfilled the validity, practicality, and sufficient criteria. Therefore, the system application will increase the quality and efficiency of industrial work practice. Socialization and dissemination of Si-Monev application are required shortly as an easy-to-use software with high mobility to get the objective and accountable results from industrial work practice program.
\end{abstract}

\section{INTRODUCTION}

Vocational high school is a mid-level institution that prioritizes the development of the students' abilities to do certain work (Rivai \& Murni, 2010: 91). The Decree Number 0490/U/1992 Article 2 by Ministry of Education and Culture Republic of Indonesia stated that Vocational High School (or Sekolah Menengah Kejuruan/SMK) aims to improve students' abilities to develop themselves in line with the development of science, technology, and art; and to prepare the students in the fieldwork and developing a professional attitude.

Industrial work practice (or Praktik Kerja Industri/Prakerin), as a program of the Double System Education (or Pendidikan Sistem Ganda/PSG) in vocational school, is a substantial part in making the educational system and vocational training relevant with the fieldwork and producing qualified graduates. Continuous learning in two places, in school and industry, forms professionality or competency level in working the main task and work function. Industrial work practice is an essential chance for vocational students because they can expand their interests and talents in one specific field.

A proper monitoring and evaluation system are two requirements to improve the learning quality that fulfilled the students' competencies and performance levels, as well as involving the cognitive, affective, and psychomotor aspects. The standard of competency achievement not only relies on the formal test, but also in the acquisition process, the application of knowledge, and skills gained through the learning process. In summary, cognitive, affective, and psychomotor aspects contribute to determining work complexity. The assessment was planned with specificity to get a transparent, directed, and comprehensive value.

Industrial work practice assessment consists of monitoring and evaluation that generally carried by the industry using assessment guide made by the school. The whole assessment system should involve the students, school counselors, and industrial infrastructures. The results should show the technical and non-technical students' competencies that in turn would be used as a feedback for the next program. However, the absence of counselor and limited infrastructure are the main reasons why the monev system has not yet accurately functioned.

The success of industrial work practice depends on, among others, implementation of comprehensive planning, performance, and assessment aspects from industrial infrastructure and school counselor. This practice utilizes an online program in an information system that operates since the planning phase until 
assessment. Industrial work practice aims to inform the students about the industry-based competency, to improve the learning and result process, and to improve the quality of the program itself.

This research aimed to produce the IT-based monitoring and evaluation system that is valid, practical, and effective to assess the vocational students' competencies, particularly those in the mechanical engineering field. The resulted product was IT-based and online Si-Monev to help school counselor and industrial instructor in monitoring and evaluating students' performances despite the time limitation.

\section{THEORETICAL FRAMEWORK}

Presidential Decree Number 8 the Year 2012 about Indonesia's National Qualification Framework (or Kerangka Kualifikasi Nasional Indonesia/KKNI) stated that the State equalizes the learning outcome through mid-level education with at least equivalent to level 2 (Chapter II Article 5 about Level and Equalisation). People with level 2 education according to KKNI are: (1) able to do a specific work by using devices, information, and commonly used work procedures, and also shows a measurable quality under the direct supervision of the supervisor; (2) having a basic operational and factual knowledge in a specific field, so as to able to resolve a problem based on the prevailing condition; (3) responsible in the own work and able to guide others. In conclusion, improvements in the character of the labor consist of work discipline, cooperation, and responsibility gained through industrial work practice.

\subsection{Double System Education in Vocational School}

Apprenticeship is the oldest vocational education system in the history of vocational education. In this system, a novice learns from the expert in a particular vocational field. The apprenticeship in a productive group are divided into three types: (1) people with the skills to increase the quality of productions, process the raw material, and utilize the production tools, (2) people without those skills and learn from the first group through apprenticeship, and (3) people who obtain skills from the first group through apprenticeship albeit lower skills and work to increase the production under the supervision from the first group. The above groups all connected and requires each other (Sudjana, 2000).
According to Sutrisno (2006), education and training are the only way to prepare competent labor to reach the comparative and competitive excellencies. This opinion is in line with Pavlova's statement (2009) where competency-based training is the leading choice by the most Western government as a model for vocational education.

Decision makers should review the concepts that are difficult to understand and performed by industry and considered the alternatives to apprenticeship. In the Virtual Learning Environment (VLEs), the decision makers support the apprenticeship and keep monitoring the skills lacked that have the potential to hinder the work, and considering the alternatives in industrial apprenticeship implementation (Wahab, 2012, 145-154).

\subsection{The Implementation of Industrial Work Practice in Vocational School}

Industrial work practice is education, training, and learning activities conducted at the workplace related to the students' competencies. The learning step is an integral part of the whole education and training. Therefore, the material learned and competency trained are relevant to the standardized graduation competency profiles.

The industrial work practice gives the students a chance to express their ability gained through school. The implementation of industrial work practice continues to be observed to obtain a correct formula so that educational institution able to act as the main instrument in the humanity process. This activity gives freedom in opinion and expression, where individual dominance is no longer a benchmark in the success of the graduation output, but participatory excellence being a stronger base in producing an excellent human resource (Tilaar, 2003: 63).

\subsection{Monitoring and Evaluation in Industrial Work Practice}

Industrial work practice requires planning by the school and the industry to implement the program effectively. The implementation requires support from an accurate, on time, relevant, and economical monitoring system. Monitoring is conducted by regularly gathering information based on specific indicators to find out whether the ongoing activities are by the agreed plans and procedures. Monitoring indicators include activity essence and appointed target during the planning, informing the program administrator when problem and obstacle occurred, and acting as feedback during evaluation. 
The DLL (Dynamic Link Library) located in Windows system directory compiles most Windows API functions. An application can exploit Windows using the functions above. Moreover, the utilization of Windows API in programming helps Delphi becomes more powerful and reliable (Nugroho, 2002).

This research also used the waterfall model sequent among several Software Engineering development based on the requirement analysis. Monitoring and evaluation system in industrial work practice was previously conducted manually with its limitations in archiving and information precision. Obtaining the requirement from the whole system for the software application marked the start of modeling.

\section{DEVELOPMENT METHOD}

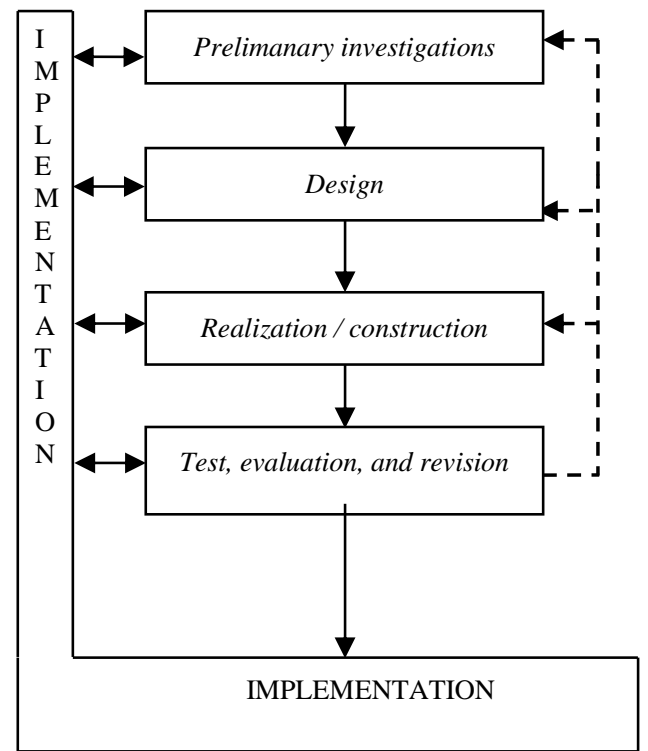

Figure 1: The general model of educational problemsolving (Plomp, 1997: 5).

This development used Plomp model because it fulfilled the criteria of validity, practicality, and effectivity. Each step of development was conducted until implementation to see the level of conformity.

Information:

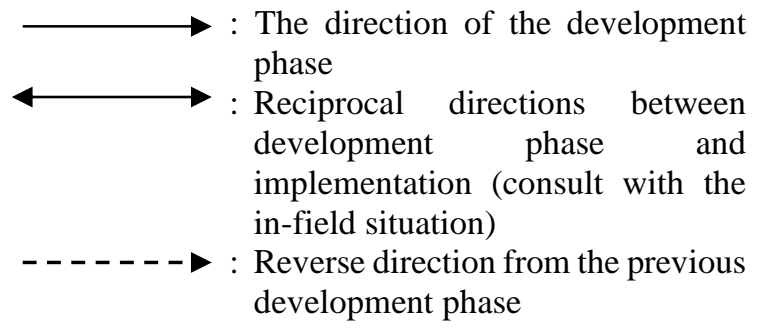


The trial activity was conducted in several steps,

There are four phases in the General Model of Educational Problem Solving from Plomp. First is the early investigation phase, continued by the designing phase, then the realization/construction phase, and lastly the test, evaluation, and revision phase with implementation phase act as the socialization step for Si-Monev in the field.

\section{RESULTS AND DISCUSSION}

The main activity in this research was predevelopment and development steps. The early investigation step was conducted to analyze (a) infield demand from the user to the developed products, (b) required competency in mechanical engineering, and (c) students' preparations before joining the industrial work practice.

The development phase was the momentum in making IT-based monitoring and evaluation system application. There were two types of Si-Monev: a guide book and software. The practical, valid, and effective concept was expected to fulfill the monitoring and evaluation function. In the development phase, a trial was conducted to find out whether the application has fulfilled the validity, practicality, and effectivity criteria.

In the assessment phase, the school counselor and the instructor made an assessment together according to the students' performances and mastered competencies. The results were an accumulated percentage of attendance, on-line teleconference participation, practicum performance, and individual reports. The attendance assessment was also accompanied with a daily report via SMS through SMS Gateway system.

Scheduled monitoring and competency evaluation utilized IT-based communication facilities. The communication required a laptop, internet via modem provided by the school or wifi provided by the industry, and headset for teleconference audio since the scheduled teleconference occurred at working hours. Teleconferences were scheduled in advance so that both sender and receiver were in online mode. Communication also occurred not only in audiovisual form but also in chat form for school documentation archives.

The assessment of industrial work practice included the process and results during the activity. The assessment mainly valued the students' success rates in mastering the ability and their attitude. The guide for industrial work practice was stated in the vocational school curriculum, covering the aspects and criteria. from the individual trial that involving several validators from experts and industrial instructor, continued with a small group trial, then an expanded trial. The expanded trial followed the industrial work practice that occurred for three months (May-June 2015) at Public Vocational High School I Sidoarjo together with six industries around Surabaya, Sidoarjo, and Gresik. There were two phases trial with 17 students, four school counselors, and nine industrial instructors. Step I comprised of two students at PT Semen Gresik, three students at PT Aneka Banu Sakti, and three students at CV Anugram Masruroh. Step II comprised of three students at PT Berliana Tbk., three students at PT Prima Alloy Steel, and three students at CV Rich Collection. The assessment results showed that students performances increased from time to time. The gradual increase in the performance indicated that $\mathrm{Si}$ Monev application motivated the students to better their performance.

Table 1: Average increasing in student performance.

\begin{tabular}{|c|c|c|c|c|c|c|}
\hline \multirow{2}{*}{$\begin{array}{c}\text { Practice } \\
\text { Material }\end{array}$} & \multicolumn{6}{|c|}{ Assessment Results } \\
\cline { 2 - 7 } & \multicolumn{3}{|c|}{ Phase I } & \multicolumn{3}{|c|}{ Phase II } \\
\cline { 2 - 7 } & A & B & C & D & E & F \\
\hline I & 68,25 & 69,50 & 69,33 & 69,75 & 70,33 & 69,67 \\
\hline II & 71,50 & 74,33 & 72,67 & 75,00 & 74,67 & 74,67 \\
\hline III & 75,50 & 76,33 & 74,00 & 77,00 & 76,33 & 78,00 \\
\hline
\end{tabular}

Observation activity, include preparation, core, and closing, was conducted in each practice material, then analyzed the reliability using Percentage Agreement (Nitko \& Brokhart, 2007: 80) as presented in Table 2.

Table 2: Percentage Agreement (PA) analysis.

\begin{tabular}{|c|c|c|c|}
\hline \multirow{2}{*}{$\begin{array}{c}\text { Partner } \\
\text { Institution }\end{array}$} & \multicolumn{3}{|c|}{$\begin{array}{c}\text { Students Activity Observation } \\
\text { Results }\end{array}$} \\
\cline { 2 - 4 } & $\mathrm{A}$ & $\mathrm{D}$ & PA \\
\hline $\mathrm{A}$ & 37 & 5 & 0,8809 \\
\hline $\mathrm{B}$ & 35 & 7 & 0,8333 \\
\hline $\mathrm{C}$ & 36 & 6 & 0,8571 \\
\hline $\mathrm{D}$ & 37 & 5 & 0,8809 \\
\hline E & 35 & 7 & 0,8333 \\
\hline F & 39 & 3 & 0,9285 \\
\hline Mean Score & 36,5 & 5,5 & 0,869 \\
\hline
\end{tabular}

The results above indicate a high average point with PA of 0.869 . The result shows that the perception of both school counselor and industrial instructor are in agreement with the increase in the students' activities as expected. 
Si-Monev application met with the practicality criteria.

\section{CONCLUSIONS AND SUGGESTIONS}

Results from Si-Monev development were as below:

1) The industrial work practice required a monitoring and evaluation system that was flexible and practical but still produced a valid result with high mobility. IT-based Si-Monev application was a breakthrough in fulfilling those criteria and fairly conducted because it involved related parties.

2) IT-based Si-Monev formulated the student's predicate in line with their performances and mastered competencies. The results integrated participatory percentage, online teleconference participatory, practice performance, and individual report.

3) Si-Monev assessment included its supporting devices fell into the 'valid and very valid' category and suitable for the industrial work practice program.

4) Si-Monev application fell under the sufficient criteria based on (a) the increase in students' performances quality, (b) consistent assessment between a school counselor and instructor, (c) the rising of monitoring quality from both instructor and school counselor, and (d) positive response from related parties.

5) The practical result of Si-Monev application showed that the application was useful in the industrial work practice program. The practicality level depended on the correct and procedural system application, it was also due to good cooperation in processing and documenting students' results.

\section{UTILIZATION SUGGESTION}

1) For the Department of Education and Culture of East Java to support the socialization and training on IT-based Si-monev by giving the time and place for the researchers during the vocationalrelated official events.

Figure 3: Participation increase in online teleconference (Phase II).

Both the figures above show the scoring increase in the online teleconference as a form of the system's effectivity. In conclusion, the level of Si-Monev implementation was elevated, which meant that the
2) Si-Monev application could inspire school counselors to familiarise themselves with IT so that they could develop diverse models for a practical assessment. 
3) Si-Monev application also acted as useful feedback between the students, between students and school counselors, and between school counselors and instructors.

4) Practicality criteria in Si-Monev application should be a consideration for the partner institutions to implement the program.

5) There should be an alternative Skype in an online teleconference using Skype with a more flexible application such as Line application in Android smartphones due to its ability to send audio and picture, but unfortunately, still, lack a saving feature.

6) IT-based Si-Monev in this research was limited only to the mechanical engineering field. The application should be implemented in other fields to obtain the effectivity rate.

\section{REFERENCES}

Hsin,C.-T., Li, M.-C., \& Tsai, C.-C. 2014. The Influence of Young Children's Use of Technology on Their Learning: A Review. Journal Educational Technology \& Society, 17(4), 85-99.

Kezkin, N.O., and Metcalf, D. (2011). The Current Perspectives, Theories and Practices of Mobile Learning. The Turkish Online Journal of Educational Technology, 10 (2), 202-208.

Milovanović, M., Obradović, J., Milajić, A. (2013). Application of Interactive Multimedia Tools in Teaching Mathematics - Examples of Lessons from Geometry. The Turkish Online Journal of Educational Technology, 12 (1), 19-31.

Nitko A.J., \& Brookhart S.M. (2007). Educational Assesment of Students. Columbus, Ohio: Fifth Edition. Pearson Merrill Prentice Hall.

Nugroho, W. (2002). Tip dan Trik Pemrograman Delphi. Jakarta: PT Elex Media Komputindo.

Pavlova, M. (2009). Technology and Vocational Education for Sustainable Development. New York: Springer.

Phing, B.S. and Kian, T. (2007). Interactive Multimedia Learning: Students' Attitudes and Learning Impact in An Animation Course. TOJET: The Turkish Online Journal of Educational Technology. October 2007, ISSN: 1303-6521 Volume 6 Issue 4. Article 3.

Plomp,T. (1997). Educational and training system design. Enschede, The Netherlands: University of Twente.

Rivai, veithzal \& Murni, Sylviana. (2010). Education Management Analisis Teori dan Praktik. Jakarta: Rajawali Pers.

Sudjana. (2000). Strategi Pembelajaran dalam Pendidikan Luar Sekolah. Bandung: Falah Production.

Sutrisno. (2006). Penyelenggaraan Sekolah Menengah Kejuruan Bertaraf Internasional. Jakarta: Direktorat Pembinaan SMK Dirjen Manajemen Dikdasmen
Tilaar, H.A.R. (2003). Kekuasaan Dan Pendidikan (Suatu Tinjauan Dari Perspektif Kultural). Magelang: Indonesia Tera.

Wahab, M.A. (2012). Rethinking apprenticeship training in the British construction industry. Journal of Vocational Education and Training, 64 (2), 145-154. 